DOI 10.37882/2223-2982.2020.11.19

\title{
ЛЕКСЕМА «ПОЭТ» В ТОЛКОВОМ СЛОВАРЕ ХХІ ВЕКА И В ЯЗЫКОВОЙ СПОСОБНОСТИ СОВРЕМЕННОГО НОСИТЕЛЯ ЯЗЫКА: К ВОПРОСУ О КУЛЬТУРНОЙ СЕМАНТИКЕ ЯЗЫКОВЫХ ЗНАКОВ
}

\begin{abstract}
THE TOKEN «POET» IN THE EXPLANATORY DICTIONARY OF THE XXI CENTURY AND IN THE LANGUAGE ABILITY OF A MODERN NATIVE SPEAKER: ON THE QUESTION OF CULTURAL SEMANTICS OF LANGUAGE SIGNS
\end{abstract}

\section{A. Kuzmina}

Summary: In this article, the ability of language signs to perform the function of the "language» of culture is considered on the example of the lexeme "poet». Russian Russian dictionary's comparison of the system meaning of the lexeme «poet» with the associative content of this unit, which is stored in the lexicon of modern students, allows us to see which «cultural» quanta of the semantics of the analyzed word are relevant in our time for the average native speaker of the Russian language.

Keywords: linguocultural studies, associative-verbal network, associative experiment, peronospera, «naive literature.»

\author{
Кузьмина Алла Васильевна \\ К.филол.н., дочент, ФГБОУ ВО «Российский \\ государственный педагогический \\ университет имени А.И. Герцена» \\ kouzmina.a.v@mail.ru
}

Аннотация: В представленной статье на примере лексемы «поэт» рассматривается способность языковых знаков выполнять функцию «языка» культуры. Сопоставление системного значения лексемы «поэт», представленного в современном толковом словаре русского языка, с тем ассоциативным наполнением этой единицы, которое хранится в лексиконе современных студентов, позволяет увидеть, какие именно «культурные» кванты семантики анализируемого слова актуальны в наше время для среднего носителя русского языка.

Ключевые слова: лингвокультурология, ассоциативно-вербальная сеть, ассоциативный эксперимент, персоносфера, «наивное литературоведение».

знании современного носителя языка.

Лексикографическое описание лексемы «поэт» позволяет увидеть её как элемент строгой и упорядоченной системы современного русского языка. В «Современном толковом словаре русского языка» под редакцией С.А. Кузнецова лексема «поэт» имеет следующую лексикографическую интерпретацию:

ПОэт, -а; м. [греч. poiētēs] 1. Автор стихотворных, поэтических произведений. Поэты и прозаики. Поэтсатирик. Фет - n. русской природы. Кто ваш любимый n.? / О художнике любого вида искусства, произведения которого отличаются поэтичностью. В своих романсах Чайковский - настоящий $n$. Среди пейзажистов непревзойдённым поэтом был Левитан. / О человеке, творчески относящемся к своему делу, страстно увлекающемся им. П. своего дела, в своём деле. 2. Тот, кто поэтически воспринимает действительность; лирик. Быть поэтом в душе. П. по натуре. Да вы настоящий $n . !$ <Поэтический (см.). Поэтов, -а, -о (1 зн.). Поэтова судьба [2].

Приведённая словарная статья демонстрирует, что в 
языковой системе начала XXI века лексема «поэт» представлена двумя лексико-семантическими вариантами. Первая семема («автор стихотворных, поэтических произведений») имеет два оттенка значения, каждый из которых формируется путём расширения первого значения, что сопряжено с утратой некоторых семантических компонентов. Второй лексико-семантический вариант («тот, кто поэтически воспринимает действительность; лирик») представляет собой переносное значение, формирующееся путём метафорического переноса.

Таким образом, словарная статья показывает нам, что лексема «поэт» не является однозначной, лишена коннотаций, стремится к многозначности, расширяет свои синтагматические возможности. Эти изменения в сочетаемости слов, отражающие перегруппировку семантических компонентов, уже являются фактом языка: они утвердились в лексической системе настолько прочно, что лексикографы зафиксировали их как переносное значение и как несколько оттенков прямого значения.

Так выглядит лексема «поэт» в системе языка. Чтобы выявить, какая информация связана с этим словом в языковой способности современного носителя языка, обратимся к экспериментальной психолингвистической методике.

Выбор свободного ассоциативного эксперимента в качестве метода исследования обусловлен несколькими причинами:

1. благодаря этой методике осуществляется верификация лексического значения слова с позиции активного носителя языка, представителя «младшей» лексической нормы, обладающему определённым набором знаний и представлений, актуальным именно в наши дни;

2. данные ассоциативного эксперимента позволяют выявить те скрытые, часто не вербализованные в лексикографических источниках семантические компоненты значения слова, которые хорошо знакомы каждому, и потому воспринимаются всеми как нечто само собой разумеющееся.

Для выявления обозначенного фрагмента языкового сознания в течение февраля-марта 2019 года была проведена серия ассоциативных экспериментов. Поскольку мы стремились максимально расширить группы реципиентов, было принято решение опросить студентов разных специальностей «Российского государственного педагогического университета имени А.И. Герцена». В качестве респондентов выступили 250 студентов 1-2 курсов, для которых русский язык является родным.

Испытуемым был предложен список из 5 слов, среди которых была лексема «поэт». Требовалось указать первые ассоциации, которые возникают в сознании при восприятии этих слов. Полученные в результате осуществлённого ассоциативного эксперимента данные позволяют составить следующее ассоциативное поле:

ПОЭТ - Пушкин 58, гений 24, стихи 18, перо 17, вдохновение 9; Есенин, Лермонтов, твореи 8; Маяковский, Пушкин А.С., рифма 6; любовь, стихотворения 5; А.С. Пушкин, Бродский, муза 4; Ахматова, душа, невольник чести, Пастернак 3; Байрон, Блок 2; анализ, анапест, Асадов, бедность; в России больше, чем поэт; величие, дар, дуэль, «Евгений Онегин», зеркало души, и гражданин, известный, интересный, кудри и баки, лирика, лекция, любимые стихи, Мандельштам, музей-квартира Пушкина, нерв жизни, несчастный; нет, я не Байрон!; образ, ода, письмо к женшине; погиб, ...; портрет в классе, поэма, признание, проза, ритм, роман, свеча горела, серебряный век, сказка о золотой рыбке, слог, страдание, талант, Тарковский, Фет, чувства лучшие, эмоции 1.

Несмотря на то, что большинство реципиентов в качестве реакций обозначили несколько слов, при формировании ассоциативного поля мы рассматривали только первое зафиксированное слово. Реконструированное ассоциативное поле включает в себя ровно 250 словреакций (при обработке ассоциативного эксперимента не было зафиксировано ни одного отказа), среди которых 65 разных реакций и 42 единичных реакций, то есть большая часть поля представлена повторяющимися 208 реакциями.

Последовательное проведение прямых параллелей и соответствий анализируемого ассоциативного поля с лексико-семантическими вариантами, представленными в толковом словаре, позволяет говорить о том, что в языковом сознании современного носителя языка актуализируется именно прямое значение лексемы «поэт». Полагаем, это дополнительно подтверждается частотной для выявленного фрагмента языкового сознания реакцией «стихи» (18) и «стихотворения» (5).

Ядерная часть полученного в ходе проведённого эксперимента ассоциативного поля «поэт» позволяет увидеть то общее «знание», которое объединяет представителей одной социальной группы: в языковом сознании современных студентов эта лексема связана прежде всего с русской культурой. Безусловно, самой сильной ассоциацией является имя А.С. Пушкина: реакция «Пушкин», зафиксированная 58 раз, дополняется вариантами ответов «Пушкин А.С.» (6) и «А.С. Пушкин» (4), а также единичными ответами «музей-квартира Пушкина» и «кудри и баки». Таким образом, именем Пушкина на слово-стимул «поэт» откликнулись 70 человек, то есть почти каждый третий из опрошенных.

Однако А.С. Пушкин - не единственный поэт, чьё имя появляется в анализируемом ассоциативном поле: голосом культурной памяти звучат имена Асадова и Aх- 
матовой, Байрона, Блока и Бродского, Есенина, Лермонтова и Маяковского, Мандельштама, Тарковского и Фета. Прелесть ассоциативного эксперимента заключается еще и в том, что, как отмечает И.А. Стернин, «используя экспериментальные психолингвистические методики исследования значения, можно ранжировать семы по яркости» [3, с.44]. И если выделить имена поэтов из фрагмента ассоциативно-вербальной сети и оформить как отдельное микрополе, также выступающими в качестве реакций, то получаем следующее: ПОЭТ - Пушкин 70; Есенин, Лермонтов 8; Маяковский 6, Бродский 4; Ахматова, Пастернак 3, Байрон, Блок 2; Асадов, Мандельштам, Тарковский, Фет 1.

Очевидна ещё одна группа реакций, представляющих собой строки любимых стихов, осколки прецедентных текстов, названия поэтических произведений: невольник чести 3; в России больще, чем поэт; «Евгений Онегин», и гражданин; нет, я не Байрон!; письмо кженщине, погиб,...; свеча горела, сказка о золотой рыбке, чувства лучшие 1.

Полученные данные, таким образом, позволяют говорить о том, что именно культурные слои ассоциаций, элементы персоносферы [4] и прецедентные феномены формируют ядро рассматриваемой лексемы «поэт». Однако культурная специфика анализируемого слова не отменяет национальную специфику его понимания.

Поэт в современной русской языковой картине мира понимается как «гений» (24) и «творец» (8); как тот творец, который, взявшись за «перо» (17) создаёт «стихи» (18) и «стихотворения» (5), получающие «признание»; тот, кто знаком с «музой»(4) и кому доступно «вдохновение» (9); тот, у кого «талант» и «дар»; тот, чьё «перо» (17) является не только изящным орудием письма, но и символом писательского труда как такового.

Интересно выглядит лексикографическое определение поэта как «автора стихотворных, поэтических произведений» в сопоставлении с развёрнутыми ассоциативными определениями, индивидуальными, единичными, но такими точными и глубокими: поэт - это «зеркало души» и «нерв жизни». И как же в связи с эти не вспомнить ещё раз любимую строчку из Евтушенко «Поэт в России больше, чем поэт...».
Полагаем, важно отметить ещё и то, как лексема «поэт» в языковом сознании среднего носителя языка ассоциативно соединена с рядом терминов литературоведения: поэт - рифма 6, анализ, анапест, лирика, образ, ода, поэма, проза, ритм, слог 1. Это уже иная тема для исследовательского разговора, но мы хотя бы просто обозначим, что эти ассоциативные сигналы «школьного знания», элементы банальной эрудиции приоткрывают для нас информацию о лексеме «поэт» как единице «наивного литературоведения» $[5,6]$.

Таким образом, осуществленное исследование позволяет сделать следующие выводы:

1. Лексикографическое представление лексемы поэт демонстрирует, что в системе современного языка это слово имеет 2 лексико-семантических варианта: на базе первого, прямого значения «автор стихотворных, поэтических текстов» оформляются два оттенка значения и фиксируется переносное значение, образованное путём метафорического переноса.

2. Фрагмент ассоциативно-вербальной сети, выявленный в результате свободного ассоциативного эксперимента, свидетельствует о том, что все ассоциации связаны исключительно с прямым значением, максимально актуальным для среднего носителя языка.

3. Ассоциативный потенциал лексемы «поэт» показывает то, что в пространстве обыденного знания среднего носителя русского языка она функционирует не только как единица лексикона: глубина понимания поэта как явления литературы (и шире - культуры), отраженная во большинстве ассоциаций, говорит о том, что в языковом сознании анализируемая лексема «живёт» как единица тезауруса и отражает национальную специфику картины мира русского народа.

4. Статистические данные подтверждают ядерный статус ассоциаций русской «культурной памяти» (44 \% реакций от числа всех ассоциаций), что великолепно иллюстрирует одну из идей В. В. Колесова: не мы живём в языке, а язык живёт в нас, храня интеллектуально-духовные «гены», переходящие из поколения в поколение [7].

\section{ЛИТЕРАТУРА}

1. Воробьёв, В.В. Лингвокультурология / В.В. Воробьёв. - М.: Изд-во РУДН, 2008.

2. Современный толковый словарь русского языка / Гл. ред. С.А. Кузнецов. - М.: Ридерз Дайджест, 2004.

3. Стернин И.А. Лексическое значение слова в речи / И.А. Стернин. - Воронеж: Изд-во Воронежского ун-та, 1985.

4. Хазагеров Г. Персоносфера русской культуры / Г. Хазагеров // Новый мир. - 2002. - №1. - С. 33-45.

5. Черняк, В.Д., Швец, А.В. «Наивное литературоведение» как фрагмент лексикона современной языковой личности» / В. Д. Черняк, А.В. Швец // Вестник 
ТГПУ. - 2006. - №5. - С. 79-84.

6. Швец, А.В. «Наивное литературоведение» в лексиконе языковой личности: Автореф. дис. канд. филол. наук/ А.В. Швец. - СПб., 2005.

7. Колесов, В.В. Жизнь происходит от слова... / В.В. Колесов. - СПб.: Изд-во СПбГУ, 2005.

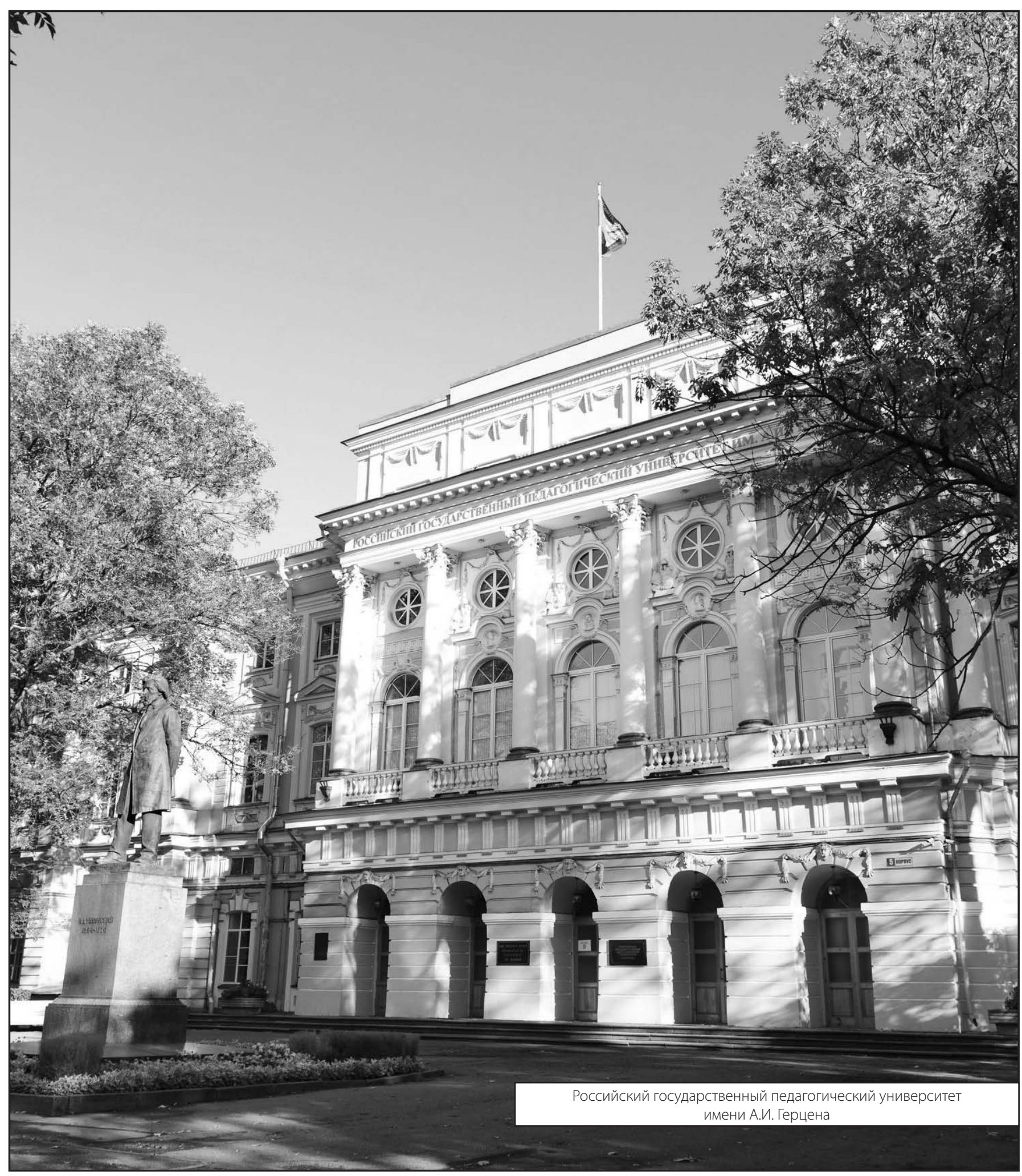

